AGRITECH, Vol. 37, No. 1, Februari 2017, Hal. 15-21 DOI: http://dx.doi.org/10.22146/agritech.15308 ISSN 0216-0455 (Print), ISSN 2527-3825 (Online) Tersedia online di https://jurnal.ugm.ac.id/agritech/

\title{
Pengaruh Kadar Air terhadap Beberapa Sifat Fisik Biji Lada Putih
}

\author{
Effect of Moisture Content on Some Physical Properties of White Pepper Seeds \\ Andi Muhammad Akram Mukhlis, Edy Hartulistiyoso, Yohanes Aris Purwanto \\ Departemen Teknik Mesin dan Biosistem, Fakultas Teknologi Pertanian, Institut Pertanian Bogor, \\ Jl. Raya Darmaga Kampus IPB Darmaga Bogor, Jawa Barat 16680, Indonesia \\ Email: edyhartulistiyoso@apps.ipb.ac.id
}

Submisi: 13 Januari 2016; Penerimaan: 22 April 2016

\begin{abstract}
ABSTRAK
Sifat fisik biji-bijian diperlukan dalam merancang suatu peralatan untuk penanganan, pemisahan, pengeringan, penyimpanan dan pengolahannya. Sifat fisik biji lada putih ditentukan sebagai fungsi kadar air pada rentang 15,40 $64,80 \%$ basis kering (b.k.). Tinggi, panjang dan lebar rata-rata pada kondisi kadar air 15,40 \% (b.k.) adalah 4,11 $\pm 0,27$ $\mathrm{mm} ; 4,35 \pm 0,34 \mathrm{~mm}$ dan 4,35 $\pm 0,35 \mathrm{~mm}$ berturut-turut. Pada rentang kadar air 15,40 - 64,80\% b.k., hasil penelitian ini menunjukkan peningkatan secara linear pada ketiga dimensi aksial, diameter rata-rata, kebulatan dari 0,969 hingga 0,977, volume dari 39,50 hingga $67,34 \mathrm{~mm}^{3}$, luas permukaan dari 55,87 hingga $79,92 \mathrm{~mm}^{2}$ dan massa seribu biji dari 52,47 hingga 75,63 g. Bulk density dan true density memiliki hubungan polinomial dengan perubahan kadar air biji. Porositas menurun dari 45,01 \% hingga 44,88 \% dengan peningkatan kadar air pada rentang 15,40 - 64,80 \% (b.k.).
\end{abstract}

Kata kunci: Kadar air; sifat fisik; biji-bjian; lada putih

\begin{abstract}
The physical properties of seed are required in designing an apparatus for handling, separation, drying, storage, and processing. The physical properties of white pepper seeds were determined as a function of moisture content in the range of $15,40-64,80 \%$ dry basis (d.b.). The average height, length and width at a moisture content condition of 15,40 $\%$ (d.b.) were $4,11 \pm 0,27 \mathrm{~mm} ; 4,35 \pm 0,34 \mathrm{~mm}$ and 4,35 $\pm 0,35 \mathrm{~mm}$, respectively. In the range of moisture content $15,40-64,80 \%$ (d.b.), the results of this study showed an increase linearly of the third axial dimension, the average diameter, the roundness from 0,969 to 0,977 , the volume from 39,50 to $67,34 \mathrm{~mm}^{3}$, the surface area from 55,87 to 79,92 $\mathrm{mm}^{2}$ and the thousand seed mass from 52,47 to $75,63 \mathrm{~g}$. Bulk density and true density has a polynomial correlation with changes in moisture content.The porosity decreased from $45,01 \%$ to $44,88 \%$ with an increase in the moisture content range of $15,40-64,80 \%$ (d.b.).
\end{abstract}

Keywords: Moisture content; physical properties; seed; white pepper

\section{PENDAHULUAN}

Lada merupakan salah satu komoditi yang memiliki nilai ekonomis tinggi. Nilai ekspor lada yang tinggi Indonesia menunjukkan bahwa sektor ini mempunyai prospek untuk dikembangkan sebagai penghasil devisa negara dari sektor nonmigas. Komoditi lada hitam dan lada putih menempati posisi tertinggi nilai ekspor Indonesia untuk sektor rempah- rempah yang diikuti oleh pala dan kapulaga, dan kayumanis. Pada tahun 2014, total ekspor dari Januari sampai November terhadap komoditi lada putih mencapai 13.082 ton dan di tahun 2015 meningkat menjadi 18.500 ton (BPS 2015).

Lada putih merupakan produk penting yang secara umum digunakan pada produk pangan yang tidak menginginkan partikel yang gelap, seperti sup, mayones, saus berwarna 
cerah, dan sebagainya. Lada putih didapatkan dari buah yang matang dengan menghilangkan kulit buahnya sebelum proses pengeringan. Lada putih diproduksi secara konvensional dari buah matang dengan teknik perendaman di dalam air. Selama proses perendaman, kulit terluar (pericarp) mengalami pelapukan dan mudah dihilangkan dengan menggosoknya kemudian dicuci dalam air bersih dan dikeringkan (Ravindran dan Kallupurackal, 2001).

Bagi Indonesia, lada merupakan komoditi ekspor dan hanya sebagian kecil saja yang dikonsumsi dalam negeri. Berdasarkan data International Pepper Community, IPC (2014) Indonesia merupakan negara penghasil lada terbesar kedua setelah Vietnam yang mampu memasok sekitar $40 \%$ dari total ekspor lada putih dunia. Oleh karena itu, sangat penting untuk mengembangkan peralatan untuk penanganan komoditi tersebut.

Proses perancangan suatu peralatan untuk penanganan, pemisahan, pengeringan, penyimpanan dan pengolahan bahan pertanian, termasuk juga biji-bijian seperti lada, memerlukan karakteristik fisik bahan. Informasi mengenai panjang, ukuran, bentuk, dan diameter penting dalam proses desain saringan pembersih ataupun penggiling (Meghwal dan Goswami, 2011). Bulk density, true density, dan porositas berkaitan dalam proses pengangkutan dan analisis ruang kerjanya, yang berguna dalam pertimbangan dalam menghitung beban struktur (Altuntaş dkk., 2005). Oleh karena ini, karakteristik fisik penting diketahui untuk mengoptimalkan perancangan peralatan untuk penanganan komoditi tersebut. Beberapa penelitian juga telah dilakukan terhadap karakteristik fisik biji dan rempah seperti lada hitam (Meghwal dan Goswani, 2011), lada merah (Üçer dkk., 2010), ketumbar (Coşkuner dan Karababa, 2007), dan biji kelabat (Altuntaş dkk., 2005).

Penelitian ini bertujuan untuk menentukan beberapa karakteristik fisik biji lada putih yang diambil dari kebun pertanian rakyat di Kabupaten Enrekang, Provinsi Sulawesi Selatan. Karakteristik fisik bahan yang akan ditentukan adalah dimensi lada, kebulatan, massa seribu biji lada, bulk density, true density, dan porositas. Karakteristik fisik bahan merupakan fungsi dari kadar air (Coşkuner dan Karababa, 2007) sehingga semua karakteristik tersebut ditentukan pada empat kondisi kadar air bahan.

\section{METODE PENELITIAN}

Biji lada putih kering varietas lokal (Kab. Enrekang) digunakan untuk semua percobaan dalam penelitian ini. Biji dibersihkan secara manual untuk menghilangkan semua benda asing seperti debu, kotoran, batu, serta biji rusak. Kadar air awal biji ditentukan dengan pengeringan oven pada suhu $105 \pm 1{ }^{\circ} \mathrm{C}$ selama 8 jam (AOAC, 1995). Kadar air awal biji adalah $15,40 \%$ basis kering (b.k.).
Untuk menghasilkan variasi sampel dengan kadar air yang diinginkan $\left(M_{\mathrm{f}}\right)$ dari kadar air awal sampel $\left(M_{\mathrm{i}}\right)$, dilakukan penambahan sejumlah massa air destilasi $\left(W_{\text {add }}\right)$ pada massa awal sampel $\left(W_{\mathrm{i}}\right)$ dengan mengikuti perhitungan dari persamaan 1 (Sacilik dkk.,2003; Coşkun dkk., 2006; Yalçin dkk., 2007).

$$
W_{a d d}=\frac{W_{i}\left(M_{\mathrm{f}}-M_{\mathrm{i}}\right)}{\left(100-M_{\mathrm{f}}\right)}
$$

Kemudian sampel dimasukkan ke dalam plastik polietilen dan ditutup rapat. Sampel dalam plastik tersebut disimpan pada suhu $5^{\circ} \mathrm{C}$ dalam refrigerator selama satu hingga dua minggu untuk memastikan kadar air bahan terdistribusi secara merata. Ketika akan melakukan pengujian, sampel yang diperlukan dikeluarkan dari refrigerator dan didiamkan sekitar 2 jam pada suhu ruang (Coşkun dkk., 2006).

Semua sifat fisik biji dinilai pada tingkat kadar air 15,40 $\%$, 34,49 \%, 53,94 \% dan 64,80 \% (b.k.) dengan tiga kali pengulangan pada masing-masing tingkatan. Rata-rata kadar air biji lada kering adalah 9,5 - 16,3 \% (b.k.) (Ravindran dan Kallupurackal, 2001).

Untuk menentukan dimensi rata-rata biji lada, secara acak 100 biji lada diambil, kemudian ketiga dimensi aksial yaitu tinggi, panjang, dan lebar diukur menggunakan mikrometer dengan ketelitian 0,01 $\mathrm{mm}$. Ketiga dimensi aksial tersebut kemudian ditentukan $a=$ sumbu terpanjang, $b=$ sumbu terpanjang yang tegak lurus terhadap $a$ dan $c=$ sumbu terpanjang yang tegak lurus $a$ dan $b$. Diameter ratarata biji dihitung dengan menggunakan rata-rata aritmatik dan geometrik dari dimensi ketiga sumbunya. Diameter rata-rata aritmatik $\left(D_{a}\right)$ dan diameter rata-rata geometrik $\left(D_{g}\right)$ dihitung dengan menggunakan persamaan 2 dan 3 (Sacilik dkk., 2003; Dursun dkk., 2007).

$$
\begin{aligned}
& D_{a}=\frac{(a+b+c)}{3} \\
& D_{g}=(a b c)^{1 / 3}
\end{aligned}
$$

Volume $\left(V_{t}\right)$ dan luas permukaan $(S)$ biji lada putih dapat dihitung menggunakan persamaan 4 dan 5 (Jain dan Bal, 1997; Baryeh, 2002; Varnamkhasti dkk.,2008).

$$
\begin{aligned}
& V_{t}=\frac{\pi B^{2} a^{2}}{6(2 a-B)} \\
& S=\frac{\pi B a^{2}}{2 a-B} \\
& \text { dimana } B=(b c)^{0,5}
\end{aligned}
$$


Kebulatan biji $\varphi$ dihitung menggunakan persamaan 6 (Coşkun dkk., 2006; Varnamkhasti dkk., 2008).

$\phi=\frac{(a b c)^{1 / 3}}{a}$

Massa seribu biji ditentukan dengan menimbang 1000 biji lada menggunakan timbangan digital dengan ketelitian $0,01 \mathrm{~g}$.

Penentuan bulk density rata-rata dilakukan dengan mengisi sampel bahan ke dalam wadah $500 \mathrm{~mL}$ dari ketinggian $150 \mathrm{~mm}$ dengan laju yang konstan, kemudian isi wadah ditimbang. Bulk density dihitung dari massa biji sampel dan volume wadah (Coşkun dkk., 2006; Zielinska dkk., 2012).

True density didefinisikan sebagai rasio antara bobot biji dan volume biji yang sebenarnya, ditentukan menggunakan metode perpindahan toluena. Toluena digunakan karena penyerapan oleh biji terjadi pada tingkat yang lebih rendah. Berat toluena yang dipindahkan didapatkan dengan mencelupkan sejumlah bahan yang telah ditimbang ke dalam toluena. Dengan demikian, volume toluene yang dipindahkan atau volume bahan dapat diketahui melalui rasio berat toluene yang dipindahkan dengan densitas toluena (Cetin, 2007; Yalçin, 2007).

Porositas dari biji-biji lada dihitung dari bulk density dan true density menggunakan persamaan 7 (Yalçin, 2007; Varnamkhasti dkk., 2008).

$\varepsilon=\left(1-\frac{\rho_{b}}{\rho_{t}}\right) \times 100$

dimana $\varepsilon$ adalah porositas dalam $\%, \rho_{b}$ adalah bulk density dalam $\mathrm{kg} \mathrm{m}^{-3}$ dan $\rho_{t}$ adalah true density dalam $\mathrm{kg} \mathrm{m}^{-3}$

\section{HASIL DAN PEMBAHASAN}

\section{Dimensi dan Sebaran Biji}

Dimensi rata-rata dari 100 biji lada putih pada kadar air $15,40 \%$ (b.k.) adalah: tinggi 4,11 $\pm 0,27 \mathrm{~mm}$, panjang 4,35 \pm $0,34 \mathrm{~mm}$, dan lebar 4,35 $\pm 0,35 \mathrm{~mm}$. Kurva distribusi frekuensi untuk nilai dimensi rata-rata menunjukkan kecenderungan distribusi normal seperti yang terlihat pada Gambar 1. Sekitar $92 \%$ biji lada putih memiliki tinggi pada rentang dari 3,5 mm sampai $4,5 \mathrm{~mm}$, sekitar $85 \%$, panjang pada rentang dari 4,0 mm sampai 5,0 $\mathrm{mm}$, sekitar $86 \%$, lebar pada rentang dari 3,5 mm sampai 5,0 mm pada kadar air 15,40\% (b.k.)

Ketiga dimensi aksial meningkat secara linear dengan adanya peningkatan kadar air biji. Hal ini menunjukkan bahwa penyerapan air akan memperbesar panjang, tinggi, dan lebar biji. Air yang masuk ke dalam biji akan menempati sel-sel di dalam biji tersebut, sehingga sel tersebut

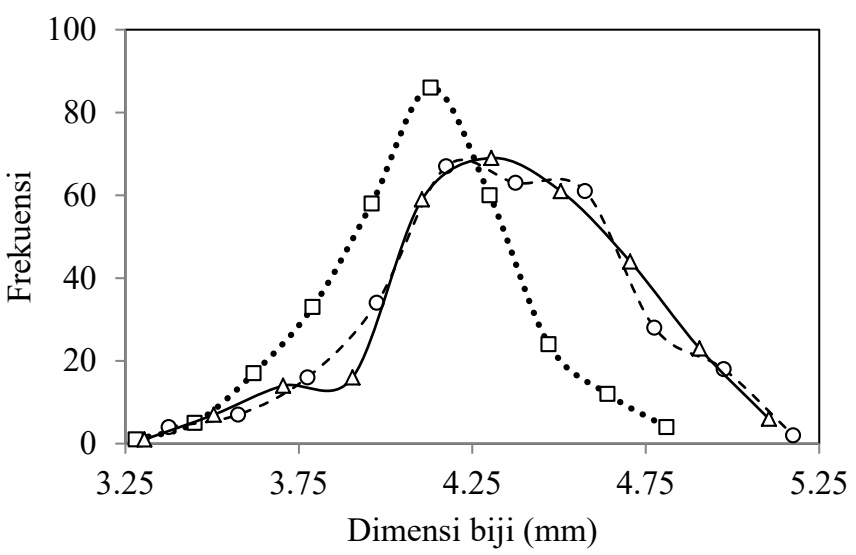

Gambar 1. Kurva distribusi frekuensi dimensi biji pada kadar air 15,40\% b.k. : ( $\square$ ) tinggi; (०) panjang dan $(\Delta)$ lebar.

akan meregang. Semakin banyak air yang diserap, akan menyebabkan peregangan semakin besar yang pada akhirnya akan meningkatkan dimensi biji (Coşkuner dan Karababa, 2007). Sumbu tinggi berada pada rentang dari 4,11 sampai 4,97, panjang berada pada 4,35 sampai 5,14, dan lebar berada pada 4,35 sampai 5,17 mm dengan peningkatan kadar air dari 15,40\% hingga 64,80 \% (b.k.) (Tabel 1).

Diameter rata-rata biji lada putih mengalami peningkatan dengan meningkatnya kadar air biji. Diameter rata-rata aritmatik meningkat dari 4,27 sampai 5,13 $\mathrm{mm}$ dan diameter rata-rata geometrik meningkat dari 4,27 sampai 5,09 mm (Tabel 1). Peningkatan diameter biji karena adanya peningkatan kadar air juga terjadi pada biji rami (Sacilik dkk., 2003), dan biji gula bit (Dursun dkk., 2007). Peningkatan diameter ini dipengaruhi oleh adanya peningkatan dimensi aksial biji karena diameter dihitung berdasarkan dimensi aksial tersebut

Hubungan antara dimensi aksial dan kadar air biji $\left(M_{c}\right)$ dapat dinyatakan dalam persamaan 8 sampai 12 .

$$
\begin{array}{ll}
T=3,8591+0,0164 M_{c} & R^{2}=0,9737 \\
P=4,1615+0,015 M_{c} & R^{2}=0,9655 \\
L=4,1496+0,0156 M_{c} & R^{2}=0,9687 \\
D_{a}=4,041+0,0164 M_{c} & R^{2}=0,9827 \\
D_{g}=4,053+0,0157 M_{c} & R^{2}=0,9734
\end{array}
$$

\section{Kebulatan}

Secara rata-rata, kebulatan biji lada putih meningkat dari 0,969 hingga 0,977 dengan meningkatnya kadar air dari 15,40\% hingga 64,80\% (b.k.). Peningkatan kebulatan biji lada putih berkaitan erat dengan adanya perbedaan peningkatan dimensi aksial karena penyerapan air ke dalam sel biji (Gambar 2). Peningkatan dimensi tinggi biji lada putih 
Tabel 1. Dimensi aksial dan diameter biji lada putih pada berbagai kondisi kadar air

\begin{tabular}{cccccc}
\hline \multirow{2}{*}{ Kadar air, \% (b.k.) } & \multicolumn{3}{c}{ Dimensi aksial $(\mathrm{mm})$} & \multicolumn{2}{c}{ Diameter rata-rata $(\mathrm{mm})$} \\
\cline { 2 - 6 } & Tinggi $(T)$ & Panjang $(P)$ & Lebar $(L)$ & Aritmatik $\left(D_{a}\right)$ & Geometrik $\left(D_{g}\right)$ \\
\hline 15,40 & $4,11 \pm 0,27$ & $4,35 \pm 0,34$ & $4,35 \pm 0,35$ & 4,27 & 4,27 \\
34,49 & $4,46 \pm 0,27$ & $4,76 \pm 0,31$ & $4,77 \pm 0,32$ & 4,67 & 4,66 \\
53,94 & $4,66 \pm 0,26$ & $4,92 \pm 0,32$ & $4,94 \pm 0,32$ & 4,88 & 4,84 \\
64,80 & $4,97 \pm 0,24$ & $5,14 \pm 0,26$ & $5,17 \pm 0,27$ & 5,13 & 5,09 \\
\hline
\end{tabular}

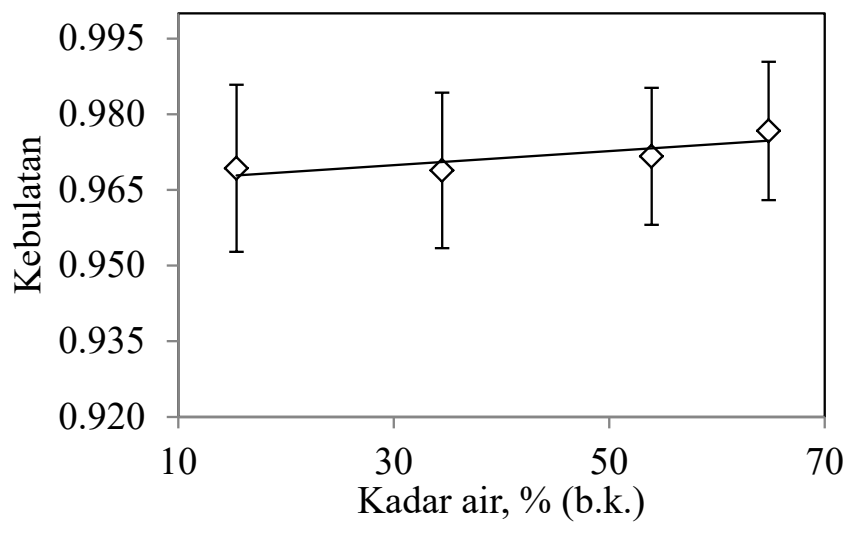

Gambar 2. Pengaruh kadar air terhadap kebulatan biji

yang lebih besar dibandingkan kedua dimensi lainnya (Tabel 1), menyebabkan kebulatan biji semakin baik. Hubungan antara kebulatan dan kadar air bahan pada 15,40 \% hingga 64,80\% (b.k.) dapat diwakili oleh persamaan 13 .

$$
\phi=0,9657+0,0001 M_{c} \quad R^{2}=0,7146
$$

Pola yang sama juga dihasilkan oleh Coşkun dkk. (2006) untuk biji jagung manis, Cetin (2007) untuk kacang barbunia, Yalçin (2007) untuk kacang tunggak, dan Sacilik dkk.,(2003) untuk biji rami. Pola yang sama ini menunjukkan bahwa karakteristik peningkatan dimensi aksial pada beberapa komoditi tersebut relatif sama.

\section{Volume Biji}

Volume biji lada putih meningkat secara linear dari 39,50 $\mathrm{mm}^{3}$ hingga $67,34 \mathrm{~mm}^{3}$ dengan adanya peningkatan kadar air biji dari 15,40\% hingga 64,80 \% (b.k.) seperti yang terlihat pada Gambar 3. Peningkatan volume biji ini disebabkan adanya peningkatan dimensi biji lada putih secara linear yang disebabkan peningkatan kadar air biji tersebut. Hubungan antara perubahan volume biji lada putih $(V)$ sebagai fungsi dari kadar air biji dapat dinyatakan dalam persamaan 14 .

$$
V=31,649+0,5273 M_{c} \quad R^{2}=0,9724
$$

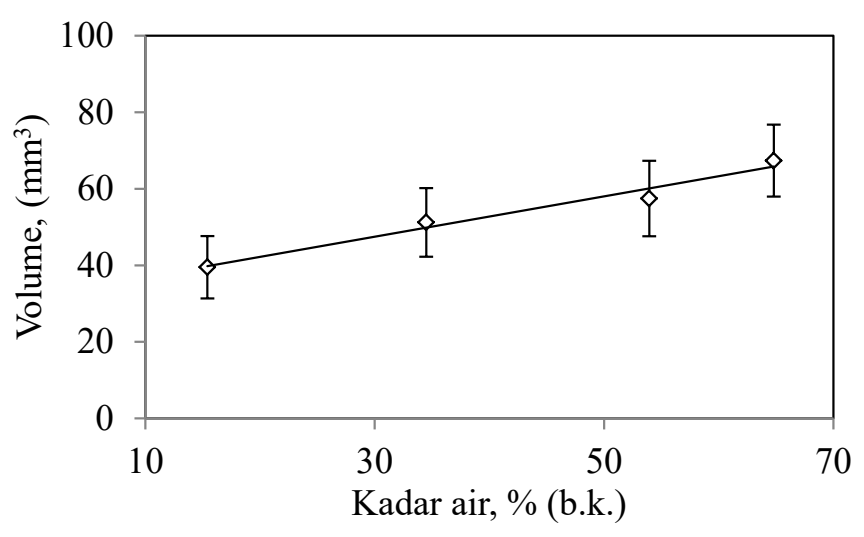

Gambar 3. Pengaruh kadar air terhadap volume biji.

Pola yang sama juga telah dilaporkan pada penelitian sebelumnya oleh Baryeh (2002) pada biji jawawut dan Altuntaş dkk. (2005) pada biji kelabat. Kesamaan pola tersebut dapat mengindikasikan bahwa karakteristik peningkatan volume biji tersebut relatif sama.

\section{Luas Permukaan}

Luas permukaan biji lada putih dihitung menggunakan persamaan 5 dengan menggunakan data ketiga dimensi aksial dari biji tersebut. Hasil yang diperoleh dapat dilihat pada Gambar 4. Terlihat bahwa, luas permukaan biji lada putih meningkat secara linear dari 55,87 $\mathrm{mm}^{2}$ menjadi 79,92 $\mathrm{mm}^{2}$ dengan adanya perubahan kadar air dari 15,40 \% hingga 64,80 \% (b.k.). Hubungan antara luas permukaan $(S)$ dan kadar air biji lada putih dapat dinyatakan dalam persamaan 15 .

$$
S=49,302+0,4563 M_{c} \quad R^{2}=0,9741
$$

Hubungan dengan pola yang sama juga dilaporkan oleh Baryeh (2002) pada biji jewawut, Sacilik dkk. (2003) pada biji rami, dan Altuntaş dkk. (2005) pada biji kelabat.

\section{Massa Seribu Biji}

Massa seribu biji lada putih $M_{1000}$ meningkat secara linear dari 52,47 g hingga 75,63 g dengan meningkatnya kadar air dari $15,40 \%$ hingga 64,80 \% (b.k.). Dengan demikian, terjadi 


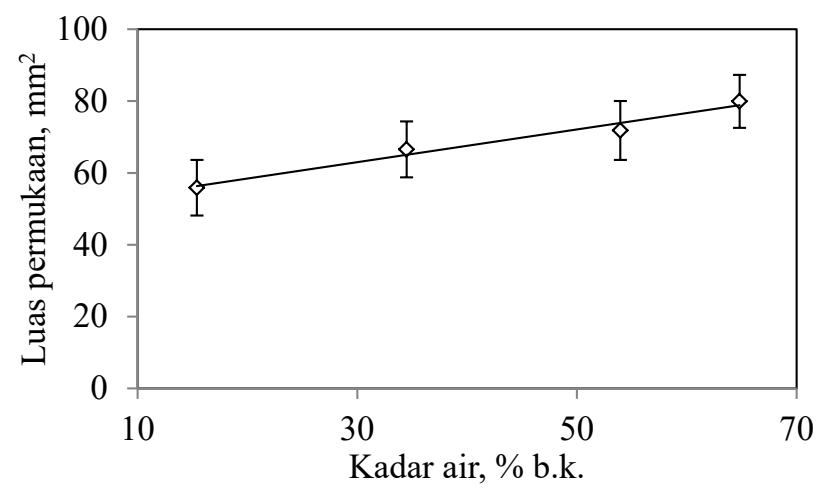

Gambar 4. Pengaruh kadar air terhadap luas permukaan biji.

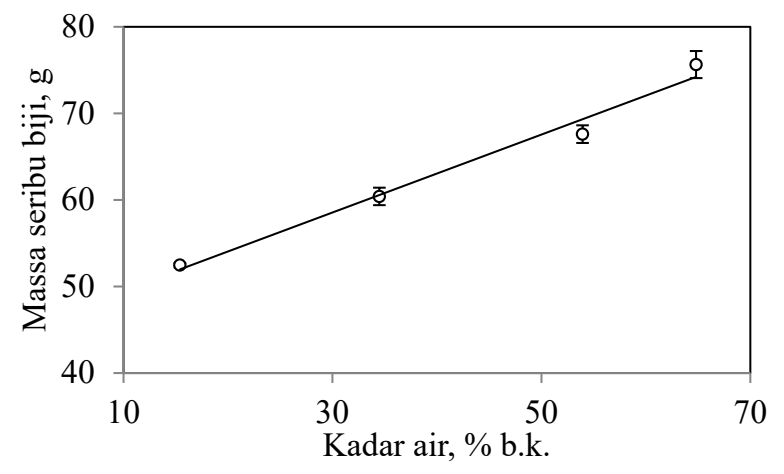

Gambar 5. Pengaruh kadar air terhadap massa seribu biji

peningkatan massa seribu biji sebesar 44,14\% pada rentang kadar air tersebut. Penambahan kadar air pada biji berarti menambahkan sejumlah massa air ke dalam biji tersebut, sehingga dalam jumlah biji yang sama (1000 biji), total massa airnya akan lebih besar (Gambar 5). Oleh karena itu, terjadi peningkatan massa seribu biji lada putih tersebut. Persamaan linier untuk massa seribu biji dapat diformulasikan menjadi persamaan 16.

$$
M_{1000}=45,047+0,4501 M_{c} \quad R^{2}=0,9821
$$

Peningkatan secara linier pada massa seribu biji lada putih dengan adanya peningkatan kadar air biji, sama halnya dengan yang telah dituliskan oleh Coşkun dkk. (2006) untuk biji jagung manis, Cetin (2007) untuk kacang barbunia dan Yalçin (2007) untuk kacang tunggak.

\section{Bulk Density}

Data eksperimental menunjukkan pola perubahan bulk density yang tidak linear pada biji lada putih dengan adanya perubahan kadar air biji lada pada rentang 15,40\% hingga $64,80 \%$ (b.k) (Gambar 6). Hubungan antara bulk density dan kadar air biji lada putih dapat diekspresikan dalam persamaan polinomial 17.

$\rho_{b}=796,52-6,0149 M_{c}+0,0684 M_{c}^{2} \quad R^{2}=0,9958$

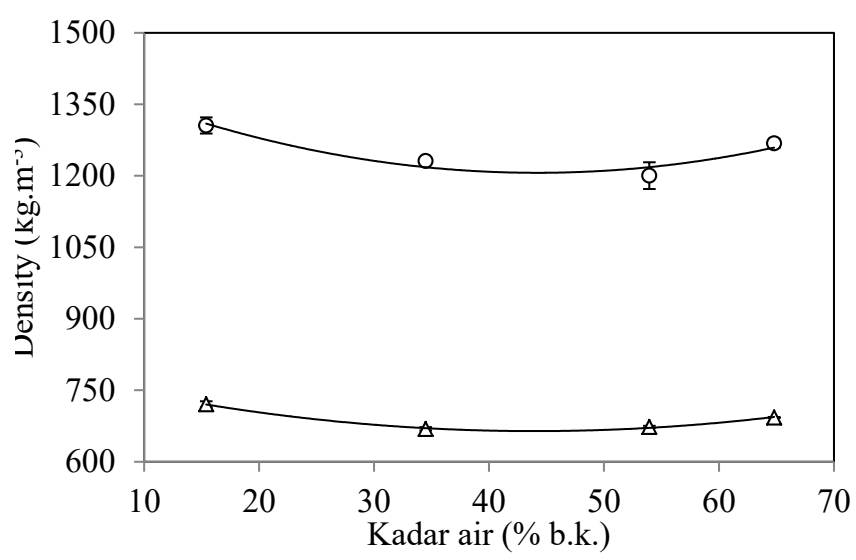

Gambar 6. Pengaruh kadar air terhadap bulk density $(\Delta)$ dan true density (०) biji lada putih.

Pada rentang kadar air biji 15,40 \% hingga 43,97\% (b.k.), bulk density mengalami penurunan dari $720,53 \mathrm{~kg}$ $\mathrm{m}^{-3}$ menjadi $664,28 \mathrm{~kg} \mathrm{~m}^{-3}$. Mulai pada titik tersebut, bulk density mengalami peningkatan dengan meningkatnya kadar air biji. Peningkatan bulk density yang terjadi pada kondisi kadar air 43,97 \% hingga 64,80 \% (b.k.) menunjukkan bahwa peningkatan berat biji sampel lebih besar dibandingkan peningkatan volume tumpukan sampelnya. Fenomena ini disebabkan oleh struktur sel pada biji sampel, dan karakteristik peningkatan volume dan massa biji dengan adanya peningkatan kadar air (Baryeh, 2002).

Hubungan polinomial antara bulk density dan peningkatan kadar air bahan juga ditemukan oleh Baryeh (2002) pada jawawut dan Baümler dkk. (2006) pada biji bunga kesumba.

\section{True Density}

Pola tidak linear juga ditunjukkan oleh perubahan true density biji lada putih terhadap adanya peningkatan kadar air biji lada putih pada rentang 15,40 \% hingga 64,80\% (b.k.) (Gambar 6). True density biji lada putih sebagai fungsi dari kadar air dapat dinyatakan dalam persamaan polinomial 18 .

$$
\rho_{t}=1449,7-11,015 M_{c}+0,1246 M_{c}{ }^{2} \quad R^{2}=0,9065
$$

True density biji lada putih mengalami penurunan dari $1.305,54 \mathrm{~kg} \mathrm{~m}^{-3}$ pada kadar air 15,40 \% b.k. hingga mencapai $1.206,26 \mathrm{~kg} \cdot \mathrm{m}^{-3}$ pada kadar air 44,20 \% b.k. Mulai dari titik tersebut, peningkatan kadar air biji akan diikuti dengan meningkatnya true density bahan. Fenomena tersebut memiliki pola yang sama dengan perubahan bulk density biji sebagai fungsi dari kadar air. Pola yang sama ini menunjukkan bahwa terdapat kesamaan karakteristik penambahan massa dan volumenya. Pada kondisi kadar air 15,40 - 44,20 \% (b.k.), peningkatan volume biji lebih besar dibandingkan 
peningkatan massa bijinya, sehingga terjadi pola menurun pada true density dan kondisi sebaliknya terjadi mulai dari kadar air 44,20 \% hingga 64,80 \% (b.k.)

Kondisi tersebut juga telah dilaporkan oleh Coşkuner dan Karababa (2007) yang menemukan pola yang sama pada perubahan true density biji ketumbar. Hubungan polinomial antara true density dan kadar air juga ditemukan oleh Baümler dkk., (2006) pada biji bunga kesumba.

\section{Porositas}

Porositas dihitung berdasarkan nilai bulk density dan true density biji lada putih. Untuk mendapatkan hasil yang relevan dengan persamaan empiris dari bulk density dan true density, nilai densitas yang digunakan berdasarkan persamaan empiris yang telah diperoleh. Berdasarkan perhitungan, porositas biji lada putih mengalami penurunan secara linear dari 45,01\% hingga 44,88 \% dengan adanya peningkatan kadar air biji dari $15,40 \%$ hingga $64,80 \%$ b.k. (Gambar 7). Terdapat dua faktor yang mempengaruhi porositas tersebut yaitu bulk density dan true density, sehingga penurunan porositas ini bergantung pada densitas biji tersebut. Hubungan tersebut dapat dinyatakan dalam persamaan 19 .

$$
\varepsilon=45,051-0,0026 M_{c} \quad R^{2}=0,9949
$$

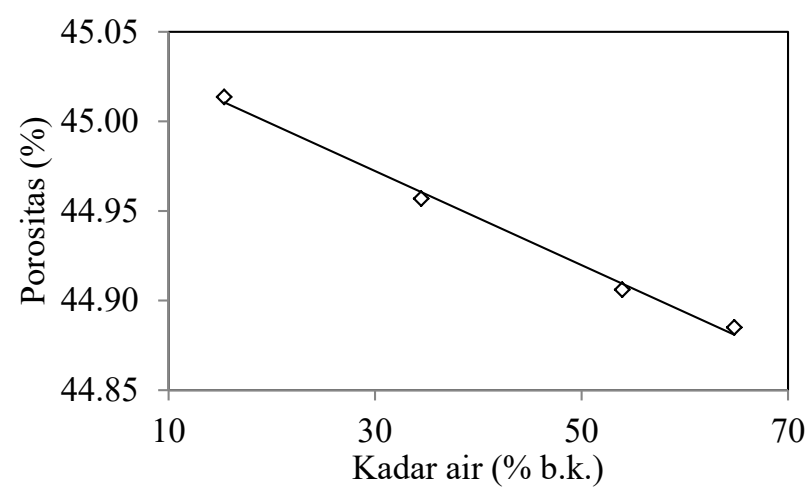

Penurunan porositas secara linear dengan adanya peningkatan kadar air biji juga ditemukan oleh Özarslan (2002) pada biji kapas, Sacilik dkk. (2003) pada biji rami, dan Dursun dkk. (2007) pada benih gula bit.

\section{KESIMPULAN}

Kesimpulan berikut diambil berdasarkan hasil penelitian ini dengan sifat fisik biji lada putih untuk rentang kadar air $15,40-64,80 \%$ (b.k.). Sifat fisik biji lada putih yang dipelajari dalam penelitian ini semuanya memiliki korelasi yang tinggi terhadap peningkatan kadar air biji. Ketiga dimensi aksial, diameter rata-rata, kebulatan, volume, luas permukaan dan massa seribu biji lada putih mengalami peningkatan secara linear dengan meningkatnya kadar air biji dari 15,40\% hingga $64,80 \%$ (b.k.). Bulk density dan true density memiliki hubungan polinomial dengan perubahan kadar air biji. Nilai minimum bulk density dan true densityyang diprediksi sebesar 664,28 kgm $\mathrm{kg}^{-3}$ dan 1206,26 kgm $\mathrm{kg}^{-3}$ secara berturut-turut. Porositas biji lada putih mengalami penurunan secara linear dari 45,01 \% hingga 44,88\% dengan peningkatan kadar air biji.

\section{DAFTAR PUSTAKA}

Altuntaş, E., Özgöz, E. dan Taşer, Ö.F. (2005). Some physical properties of fenugreek (Trigonella foenum-graceumL.) seeds. Journal of Food Engineering 71: 37-43.

AOAC (Association of Official Analytical Chemist) (1995). Official Method of Analysis of Association of Official Analytical Chemist. Ed ke-14. AOAC Inc, Airlington.

Baryeh, E.A. (2002). Physical properties of millet. Journal of Food Engineering 51: 39-46.

Baümler, E., Cuniberti, A., Nolasco, S.M. dan Riccobene, I.C. (2006). Moisture dependent physical and compression propertiesof safflower seed. Journal of Food Engineering 72: 134-140.

BPS (Badan Pusat Statistik). (2015). Buletin Statistik Perdagangan Luar Negeri. Badan Pusat Statistik.

Cetin, M. (2007). Physical properties of barbunia bean (Phaseolus vulgaris L. cv. 'Barbunia') seed. Journal of Food Engineering 80: 353-358.

Coşkun, M.B., Yalçin, I. dan Özarslan, C. (2006). Physical properties of sweet corn seed (Zea mays saccharata Sturt.). Journal of Food Engineering 74:523-528.

Coşkuner, Y. dan Karababa, E. (2007). Physical properties of coriander seeds (Coriandrum sativumL.). Journal of Food Engineering 80: 408-416.

Dursun, İ., Tuğrul, K.M. dan Dursun, E. (2007). Some physical properties of sugarbeet seed. Journal of Stored Products Research 43: 149-155.

IPC (Internasional Pepper Community). (2014). Pepper Statistical Yearbook 2014.

Jain, R.K. dan Bal, S. (1997). Properties of pearl millet. Journal of Agricultural Engineering Research 66: 8591.

Meghwal, M. dan Goswami, T.K. (2011). Thermal Properties 
of Black Peppers and Its Volatile Oil. Journal of Agricultural Engineering 48: 8-14

Özarslan, C. (2002). Physical properties of cotton seed. Biosystems Engineering 83: 169-174.

Ravindran, P.N. dan Kallupurackal, J.A. (2001). Black pepper. Dalam: Peter, K.V. (ed.). Handbook of Herbs and Spices, hal 62-110. Woodhead Publishing Limited, Cambridge.

Sacilik, K., Öztürk, R. dan Keskin, R. (2003). Some physical properties of hemp seed. Biosystems Engineering 86: 191-198.

Üçer, N., Kılıçkan, A. dan Yalçın, I. (2010). Effects of moisture content on some physical properties of red pepper (Capsicum annuum L.) seed. African Journal of
Biotechnology 9: 3555-3562

Varnamkhasti, M.G., Mobli, H., Jafari, A., Keyhani, A.R., Soltanabadi, M.H., Rafiee, S. dan Kheiralipour, K. (2008). Some physical properties of rough rice (OryzaSativaL.) grain. Journal of Cereal Science 47: 496-501.

Yalçin, İ. (2007). Physical properties of cowpea (Vigna sinensisL.) seed. Journal of Food Engineering 79: 5762.

Yalçin, İ., Özarslan, C., Akbaş,T. (2007). Physical properties of pea (Pisum sativum) seed. Journal of Food Engineering 79: 731-735

Zielinska, M., Zapotoczny, P., Białobrzewski, I., ZukGolaszewska, K. dan Markowski, M. (2012). Engineering properties of red clover (Trifolium pratense L.) seeds. Industrial Crops and Products 37: 69-75 